\title{
Status of Farm Mechanization and Women Participation in Agriculture in Balod District, India
}

\author{
Dipti Sahu $^{1^{*}}$ and Vinod Kumar Sahu \\ ${ }^{1}$ Department of Farm Machinery and Power Engineering, Vaugh School of Agricultural \\ Engineering and Technology, Sam Higginbotton Institute of Agriculture, Technology and \\ Science, Allahabad (U.P.), India \\ ${ }^{2}$ Chhattisgarh Agriculture Engineering college, Bhilai, Durg(Chhattisgarh) \\ *Corresponding author
}

\section{A B S T R A C T}

\begin{tabular}{|l|}
\hline Key w ord s \\
Farm \\
mechanization, \\
Women \\
participation \\
\hline Article Info \\
\hline Accepted: \\
05April 2020 \\
Available Online: \\
10 May 2020 \\
\hline \hline
\end{tabular}

Farm mechanization means the introduction and use of non-biological power in carrying out various operations. The mechanization in the farm sector has to take several factors into considerations; it facilitates the speedy completion of farm operations with much ease. Farm mechanization is a different area of high-tech agriculture, in which modern machine are being put to use for land preparation, land development, inter culture operations, sowing transplanting harvesting threshing etc. The contribution of draught animal power in India has witnessed the most prominent change through decrease from $45.3 \%$ in 1971 to $8.02 \%$ in 2012.

\section{Introduction}

Farm mechanization has been helpful to bring about a significant improvement in agricultural productivity. Thus, there is strong need for mechanization of agricultural operations. The factors that justify the strengthening of farm mechanization in the country can be numerous. The timeliness of operations has assumed greater significant in obtaining optimal yields from different crops, which has been possible by way of mechanization. However draft animals, particularly bullocks/he buffaloes/camel; still continue to be a predominant source of energy for traction and rural transport in different parts of India. Today draft cattle provide about 50 million hp or about 35 million $\mathrm{kW}$ of energy in a year. More than 65 per cent of this energy is used for agriculture and the rest for transport. Over 150 Mha of land, farming about 65 per cent of the area sown, is cultivated through the use of draft animals every year. Chhattisgarh State is known as a rice bowl where rice culture is predominantly rain fed and approximately $85 \%$ of the rice 
crop in this region is direct-seeded. Most of the area is under a single cropping system. Rural women contribute much of the labor for rice production and other agricultural activities. More than $50 \%$ of the farm work is done by women in India Contributions of farm women in agriculture cannot be ignored. The total agriculture workforce in India is $234,270,000$ as per 2001 census, of which $38.99 \%$ is contributed by female workforce and $60.93 \%$ is male workforce. In agriculture sector, out of the total women engaged, more women are employed as agriculture laborers rather than as cultivators both in absolute terms and as proportionately.

The main objectives of this study to record the utilization of tractor and animal power utilization for agricultural operations.

\section{The specific objectives of this study were}

\section{Power availability}

Indian farms had only $0.295 \mathrm{~kW} /$ ha in 1971 , dominated power (45.26\%). The power availability, however, increased over year at growth rates to $4.79,4.89 \%$ in each ten year till 1991. The contribution of draught animal power has witnessed the most prominent change through decrease from $45.3 \%$ in 1971 to $8.02 \%$ in 2012 . The increase in power has been mainly through introduction of tractors, whose contribution has increased from $7.5 \%$ in 1971 to $46.7 \%$ in 2012. Presently total power availability in Chhattisgarh is 1.09 $\mathrm{kW} / \mathrm{ha}$. and contribution of animal and human power is $27.4 \%$ and $48.39 \%$ respectively however animal farming cover about $40 \%$ of cultivated area.

On an average $80 \%$ farmers have land holding less than 2 hectare. The small and marginal farmers do not have the capacity to purchase improved costly machinery or tractor. So they are dependent on the animals only. Chhattisgarh agriculture continues to be dependent upon human and bovine population. Tractor, power tiller, diesel engine and electric motor have supplemented the animate power. Among draft animals, bullock and He-buffaloes are used for farming operations in Chhattisgarh.

Two villages were selected in each of 5 disparate areas, one with access to mechanized cultivation, the other without. Data were collected weekly over 15 months from a random sample of 36 farmers in each village on use of family and hired labour, draft animals and farm machinery (owned and hired), input levels, and production and disposal of output. The final conclusion is that, taking into account the full costs to society of deploying and using tractors, there must be serious doubt whether expanded mechanization is desirable; however, there is a strong case for developing animal power, associated equipment and techniques.

The present status and future trends of comparative demand and utilization of draft animals and tractors on Indian farms. Utilization of available farm power, economic and social restraints and economic aspects of hiring tractors, bullocks and power tillers are outlined and brief case studies of powered machinery use for cultivation are presented.

\section{Materials and Methods}

Chhattisgarh state has been divided into three Agro-climatic zone viz. Chhattisgarh plains, Bastar Plateau and Northern Hill zone, covering $51.0 \%, 28.0 \%$ and $21.0 \%$ of the geographical area, respectively. The district from the Chhattisgarh plains was selected. Out of which two blocks namely Gunderdehi and Gurur block has been identified for the purpose of study. Two villages from each block were selected for conduction of data 
collection work. In this study 30 farmers including women from each of the village (total four) were interviewed personally for recording all necessary observation as per proforma developed.

The Normal rainfall is $1478 \mathrm{~mm}$ in the district. Total $889 \mathrm{~km}^{2}$ area of the district is covered by forest. Agriculture is the main occupation of the district. Net sown area is $2645.59 \mathrm{~km}^{2}$ (on 2000 data) with only 672.02 $\mathrm{km}^{2}$ is double cropped area. Principal crop is rice sown in $2605.62 \mathrm{~km}^{2}$ areas i.e. $98.34 \%$ of total sown area. $99.66 \%$ villages where provided with drinking water source. Almost $90 \%$ of drinking water supply is from Ground Water in the district. Total hand pumps are 5776 whereas power pumps are 3153 tapping ground water in the district. 84 water supply schemes are running tapping ground water in the district.

\section{Method of data collection}

The data were collected through personal interview of the farmers and farmwomen on the pre - tested proforma (Appendix - A) by using recall method for all the selected farmers falling in different categories. The information about household activities was collected through interview of the counterparts of the farmers. Actual observations of some activities were also recorded during the field operations in a few villages. The time and labour required for various farm operations mainly field preparation, sowing, transplanting, irrigation, manuring, fertilizer application, weeding, plant protection, harvesting, threshing, drying and transportation were recorded for each crop under study on the basis of the verbal interview of the farmers. Thus the data in terms of time and labour required to accomplish different field operations and household activities along with other basic information were collected individually from all the selected farmers.

\section{Data processing}

Adopting standard techniques suggested by the research workers the data thus collected was processed. First of all the data for animal power utilization was arranged separately for different categories of respondents for each village. The values thus found were arranged in tabular form separately for each category of farmers.

\section{Involvement of farm women in a operation}

It indicates the per cent of the respondents involvements in the particular operation. If the involvement of farm women in intercultural operation was $89.96 \%$ means out of 100 respondents 89 respondent were involved in this operation.

\section{Sampling procedure}

The main focus of study was on the animal power utilization, tractor power utilization and farm women and their involvement in agriculture and allied activities in the state. Therefore, only the draught animal, farm women and male farmers were considered separately for the study. To identify the location of survey sites in the selected district of the zone villages were grouped block wise. The farmers were selected randomly. After that population of the farmers were grouped under different categories for all the four villages. The categories viz. marginal (<1ha), small (1-2ha), semi-medium (2-4ha), medium (4-6ha) and large ( $>6 \mathrm{ha}$ ) of farmers, selected in each of the village.

\section{Results and Discussion}

This chapter briefly presents the findings of the survey conducted in Durh Balod district of C.G. Plains region. To find out the animal power utilization and women's power contribution in agriculture and allied activity under existing farm practices, a detailed 
survey of farm families comprising of different land holding sizes was conducted. Survey revealed that the respondents belong to different castes, and have education level from illiterate to college level. Many farmers, especially those who have their own irrigation sources, take summer paddy also.

\section{General and social attributes}

The population density of Chhattisgarh state is 154 and in the district it is 342 persons per $\mathrm{km}^{2}$. The sex ratio of state and district is very similar to each other ranges between 989 and 999 female per thousand males. The main dialect of the district is chhattisgari. District has mainly backward class population and tribes like Satnami, Gond, Kanwar etc, are found in the district. District is well connected with the rest of the state through road and the two tehsils namely, Gunderdehi and Dondi are connected with railways. $98.15 \%$ villages of the district are electrified.

Table.1 Administrative Information

\begin{tabular}{|c|c|}
\hline Subdivisions & 02- (Balod, Durg,) \\
\hline Tahsils & $\begin{array}{l}\text { 08-( Balod, Gurur, Dondi, Gunderdehi,Dondi } \\
\text { Lohara ,Durg,Patan, Dhamdha ) }\end{array}$ \\
\hline R.I. Mandal & $\begin{array}{l}\text { 9- ( Balod, Gunderdehi, Gurur, Dondi, Dondi } \\
\text { Lohara, Arjunda, , Patan, Dhamdha, Bhilai) }\end{array}$ \\
\hline Patwari Halka & Total- 232 \\
\hline $\begin{array}{l}\text { Blocks/Janpad } \\
\text { Panchayat }\end{array}$ & $\begin{array}{l}06 \text { - ( Gunderdehi, Gurur, Dondi, Dondi Lohara, } \\
\text { Patan, Dhamdha) }\end{array}$ \\
\hline Panchayats & Total -522 \\
\hline Villages & $\begin{array}{l}\text { (a) Revenue Villages- 913, (b) Forest Villages- } 2 \text {, } \\
\text { (c) Total Villages- } 915\end{array}$ \\
\hline Municipality & - (Balod, Durg) \\
\hline Nagar Panchayat & $\begin{array}{l}\text { 08-( Balod, Gurur, Dondi, Gunderdehi, Dondi } \\
\text { Lohara, Durg, Patan, Dhamdha ) }\end{array}$ \\
\hline
\end{tabular}


Table.2 Population of draught animal power and use of implements

\begin{tabular}{|c|c|c|c|c|c|}
\hline \multirow[t]{2}{*}{ S. No } & \multirow[t]{2}{*}{ Particulars } & $\begin{array}{l}\text { Gunderdehi } \\
\text { Block }\end{array}$ & \multirow[b]{2}{*}{ Sikosa } & \multirow{2}{*}{$\begin{array}{l}\text { Dondilo } \\
\text { hara } \\
\text { Block } \\
\text { Lohara }\end{array}$} & \multirow[b]{2}{*}{ Dewari } \\
\hline & & Arjunda & & & \\
\hline 1 & Total Area (ha) & 537.452 & 569.398 & 586.621 & 687.907 \\
\hline 2 & Cultivable Area (ha) & 409.314 & 422.153 & 439.900 & 542.923 \\
\hline 3 & Irrigated Area (ha) & 409.314 & 422.000 & 427.000 & 405.000 \\
\hline \multirow[t]{3}{*}{4} & Major Crop Grown & & & & \\
\hline & (a) Kharif & \multicolumn{2}{|l|}{ Paddy, Arhar } & & \\
\hline & (b) Rabi & \multicolumn{4}{|c|}{ Wheat, Bengal Gram, Sarso, Tiwra, Alsi } \\
\hline 5 & Major Crop Rotation & \multicolumn{2}{|c|}{ Paddy, Wheat, Moong } & & \\
\hline 6 & No. of Farm families & 342 & 408 & 482 & 805 \\
\hline 7 & Bullocks (Nos.) & 10 & 16 & 138 & 193 \\
\hline 8 & He-buffaloes (Nos.) & 200 & 250 & 240 & 316 \\
\hline 9 & Tractors (Nos.) & 9 & 14 & 22 & 9 \\
\hline 10 & $\begin{array}{l}\text { Power Tiller Reaper } \\
\text { (Nos.) }\end{array}$ & 2 & 3 & 3 & 0 \\
\hline 11 & Country Plough (Nos.) & 105 & 256 & 327 & 342 \\
\hline 12 & Bollock Cart (Nos.) & 104 & 254 & 322 & 340 \\
\hline 13 & Gobar Gas Plant (Nos.) & 8 & 0 & 7 & 36 \\
\hline 14 & Vermi Compost (Nos.) & 10 & 0 & 0 & 0 \\
\hline 15 & Tube Well (Nos.) & 7 & 2 & 6 & 4 \\
\hline 16 & Electric Motor (Nos.) & 20 & 30 & 11 & 5 \\
\hline 17 & Diesel Engines (Nos.) & 30 & 70 & 9 & 16 \\
\hline
\end{tabular}




\section{Table.3}

\begin{tabular}{|c|c|c|c|c|}
\hline & $\begin{array}{l}\text { Tractor use in } \\
\text { different } \\
\text { agricultural } \\
\text { operation }\end{array}$ & $\begin{array}{l}\text { Average annual } \\
\text { agril. use of } \\
\text { tractor for } \\
\text { personal land } \\
\text { (h) } \\
\text { (\%) }\end{array}$ & $\begin{array}{l}\text { Average annual } \\
\text { agril. use of } \\
\text { tractor for custom } \\
\text { service land } \\
\text { (h) } \\
(\%)\end{array}$ & $\begin{array}{l}\text { Average annual } \\
\text { other use of } \\
\text { tractor for custom } \\
\text { Service } \\
\text { (h) } \\
\text { (\%) }\end{array}$ \\
\hline \multirow[t]{2}{*}{1.} & Tillage & 56 & 42 & ----- \\
\hline & & $(14.66 \%)$ & $(10.99 \%)$ & \\
\hline \multirow[t]{2}{*}{2.} & Sowing & 30 & 37 & ----- \\
\hline & & $(7.85 \%)$ & $(9.69 \%)$ & \\
\hline \multirow[t]{2}{*}{3.} & Leveling & 4 & 9 & ----- \\
\hline & & $(1.05 \%)$ & $(2.36 \%)$ & \\
\hline \multirow[t]{2}{*}{4.} & Threshing & 20 & 37 & ----- \\
\hline & & $(5.24 \%)$ & $(9.69 \%)$ & \\
\hline \multirow[t]{2}{*}{5.} & Transportation & 32 & 39 & ----- \\
\hline & & $(8.38 \%)$ & $(10.21 \%)$ & \\
\hline \multirow[t]{2}{*}{6.} & Irrigation & ----- & 3 & ----- \\
\hline & & & $(0.79 \%)$ & \\
\hline \multirow[t]{4}{*}{7.} & Annual & 14 & ----- & 59 \\
\hline & miscellaneous use & $(3.66 \%)$ & & $(15.45 \%)$ \\
\hline & Total & 156 & 167 & 59 \\
\hline & & $(40.85 \%)$ & $(43.72 \%)$ & $(15.45 \%)$ \\
\hline
\end{tabular}

Fig.1 Category wise population in different blocks

\begin{tabular}{|c|c|c|}
\hline \multirow{7}{*}{ 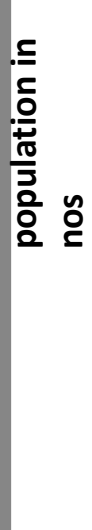 } & 150000 & \\
\hline & 100000 & SC \\
\hline & & ST \\
\hline & 50000 & MINORITY \\
\hline & P & RUARL \\
\hline & & URBAN \\
\hline & & \\
\hline
\end{tabular}


As per 2011 census the male, female and total literacy is $82.21 \%, 50.41 \%$ and $66.26 \%$, respectively. Details of general information of the district and surveyed villages are summarized and shown in Fig.

In conclusion, this study undertaken in investing the effect of status of farm mechanization in agriculture utilization pattern of farm tractors in different agricultural operations for own land and for custom service in rabi and Kharif season , which revealed that the average annual use of the tractors was $382 \mathrm{~h}$ only in the district out of which for $59.16 \%$ of the time, the tractors were used for custom work and that of $40.85 \%$ of the time, for own work.

Maximum use of the tractor for $98 \mathrm{~h}(25.65 \%)$ was recorded in tillage operation, followed by threshing operation $57 \mathrm{~h}(14.92 \%)$ and sowing operation $67 \mathrm{~h}(17.53 \%)$.In the custom work, the maximum use of the tractors was found in tillage and transportation operations $42 \mathrm{~h}$ $(10.99 \%)$ and $39 \mathrm{~h}(10.21 \%)$, where as for own work, maximum use of the tractor was found was found in tillage operation $(14.66 \%)$.

\section{References}

Aggarwal, M. 2003. Economic Participation of Rural Women in Agriculture. Economic Empowerment of Rural
Women in India, Edited by Gopal Singh 2003, RBSA Publications Jaipur, Rajasthan.

Anonymous. 1995. Utilization of animal energy through effective animal machine system in Baster region. Final report of ICAR Ahhoc project. Pp. 1-69. Anonymous. 2001. Empowerment of Women in Agriculture, Policy Paper11; National Academy of Agricultural Science, India, September 2001.

Anonymous. 2005. The Kamdhenu bullocks drawn tractor. Bhartiya Cattle Resource Development Foundation. Rajasthan. Website www.cowindia.org Bargali, S.S., Pandey, K., Singh, L. and Shrivastava, S.K. 2009. Participation of rural women in rice-based agroecosystems. IGKV, Raipur.

Chandurkar, P.S. 2001. Training and education on IPM. IPM Mitr. 11:91-97.

Chaudhary, H. and Singh, S., 2003. Farm Women in Agriculture Operations. Agricultural Extension Review. 15(1): 21-23.

Chaudhury, Sarmishtha. 2004. Invisible Activities of Rural Women. Kurukshetra, Vol. 52, No. 9, July 2004.

Dave, A.K. 1999. Animal drawn tillage system for rice cultivation under rainfed condition. Agricultural Mechanization in Asia, Africa and Latin America, 30(3): 28-30.

\section{How to cite this article:}

Dipti Sahu and Vinod Kumar Sahu. 2020. Status of Farm Mechanization and Women Participation in Agriculture in Balod District, India. Int.J.Curr.Microbiol.App.Sci. 9(05): 501507. doi: https://doi.org/10.20546/ijcmas.2020.905.056 